\title{
II. Life of M. Le Roy
}

\section{T. S. Evans}

To cite this article: T. S. Evans (1808) II. Life of M. Le Roy , Philosophical Magazine Series 1, 31:121, 4-8, DOI: $10.1080 / 14786440808563841$

To link to this article: http://dx.doi.org/10.1080/14786440808563841

曲 Published online: 18 May 2009.

Submit your article to this journal

Џ Article views: 2

Q View related articles $₫$ 


\section{[ $4 \begin{array}{ll}4 & ]\end{array}$}

\section{Life of $M$. LE Roy.}

\section{To Mr. Tilloch.}

$\mathrm{T}_{\mathrm{HE}}^{\mathrm{SIR}}$

1 HE following account of Julien Le Roy, the celebrated watch-maker*, is an abridgment of that given by his son, in a work of his entitled Etrennes Chronométriques; and if you think it will prove interesting to any of your numerous readers, it is very much at your service.

I remain, sir, yours, \&c. \&c.

T. S. Evans.

Royal Military Academy,

Woolwich.

Julien Le Roy was born at Tours in 1686 , and died at Paris in 1759. He had hardly attained his twelfth year when his taste for clock-and watch-work first showed itself. His hours of recreation were constantly employed in finishing some pieces of mechanism, and in reading with avidity all books relating to that subject and natural philosophy. About the age of thirteen, he constructed some small pieces of clock-work; and finding the day not sufficiently long for him, he sat up during the night, to study how he might improve their motions.

With so remarkable a desire to increase his knowledge in this art, which his parents lost no opportunity of improving and applying to the best advantage, it was impossible for him not to make a very rapid progress. At the age of 17 , he went to Paris, and was admitted in $1 ; 13$ into the company of watch-makers of that city.

His merit having introduced him to the acquaintance and esteem of the most distinguished men of his time, he very shortly became celebrated for the excellence of his work manship; and for a quickness of execution that appeared

* Father of Pierre Le Roy, who wrote the Memoir on the best method of measuring time at sea, which you have honoured with a place in your Magazine, (vol. xxvi. p. 40, ) and the inventor of the compensation balance, which has since been improved and applied with such success by our English artists. 
almost incredible : so much so, that he very soon left all his masters far behind him.

It is well kuown that the English, on account of their numerous discoveries in this art, had enjoyed such a reputation for the excellence of their clocks and watches, that they universally found a market in preference to any others in all parts of the known world; and that the French themselves were obliged to purchase theirs in England. Julien Le Roy had the honour of removing part of this pre-eminence, and of transferring it to the French artists. We must refer to the account itself given of him for the various means which he employed to effect this, as they would be superfluous here; and it will be sufficient to mention in a few words the principal discoveries which he made:-His repeating clocks and watches: his improved seconds and horizontal clocks : his universal compass card with a sight; an extremely useful and simple contrivance for drawing a meridian line, and finding the declination of the needle: his clocks and watches of three parts, and his new universal horizontal dial. It is to him also that watch-makers are indebted for the method of compensating for the effects of heat and cold in the balances of chronometers, by the unequal expansion of different metals; a discovery of the greatest importance, which has been brought by our English artists to a state of perfection hardly credible, although it had been condemned and thrown aside by the inventor's son, M. Pierre Le Roy. See vol. xxvi. p. 200, of the Phil. Magazine.

Such a number of things so bappily invented, and executed, procured him the reputation of the first artist in his profession. The celebrated Grabam once paid him the following compliment before several persons, when a repeater of Le Roy's was shown him by lord Hamilton. After having examined it for some time, he said, "I could wish I were younger, that I might work from this model." Which justice done to his merit by the first watch-maker in Eurppe at that time, was afterwards universally rendered him by all artists who had arrived to any degree of excellence in the art. 
The general eagerness to obtain watches of his invention soon became so great, that the watch-makers of Geneva engraved his name, instead of those of Tompion and Graham, on the common watches made at that place*.

It was not among foreigners only that he enjoyed so flattering a consideration. In his own country he was distinguished as he merited. He obtained in 1739 apartments in the galleries of the Louvre, and the title of clock- and watchmaker to the king. Cardinal Fleury, when he sent him this title, told him that his majesty, pleased with his services, might hereafter add to this favour by granting him a pension. Our artist, however, thought that a sovereign, like the father of a family, could not settle one of his children above the level of the rest, without altering in some degree the patrimony of the others; and therefore, that the wishes of an honest man and a true patriot ought to be satisfied when he has obtained some mark of esteem and benevolence from his sovereign.

"If this celebrated artist," arlds his son, "has enriched clock-and watch-work so much by his discoveries and workmanship, his generous conduct to those who, under his direction, cultivated this art, has not less contributed to its perfection. I appeal to all those who were acquainted with him, to prove the truth of this assertion. Never was any man more accessible, more communicative, or more prodigal of his knowledge. Has he not taken as much pains to place his work before the eyes of the gentlemen of the art, as the English took at first to hide theirs? What artist is ignorant of the trouble which he gave himself to expose new inventions, when they were as rarely known as they are now common? Who does not know that he sacrificed a part of his fortune? that he did not confine himself merely to the encouraging of them by his example, but that he even added

* I met with the following anecdote lately in a French work:

Voltaire called one day on Pierre Le Roy the son, and the conversation happened to turn upon the father's improvements in watch-and clock-work. After Le Roy had expatiated on them for some time, Voltaire replied, "Yek, yes, my friend, marsha! Sare and your father have beat the English,"-T. S.E. 
recompenses, as far as.his circumstances would permit? After a life so spent, can we be astunished at the concourse of workmen who followed his funeral? Can we be surprised at their expressing with sorrow, that they had lost their supporter! their friend! their father ?"

After having considered the good qualities for which Julieri Le Ròy was so much admired and cherished as an artist by all who were intimate with him, let us turn to a few traits in his life, from which we may judge of those that distinguished him as a man and a member of society. He had been very intimate with Henry Sully; and the pleasure which these two celebrated men found in discoursing together of their art, so far from exciting envy, had formed between them the bond of the closest and most sincere friendship. When the watch-manufactories of Versailles and St. Germain were broken up, Sully tried to persuade his friend to accept a pension from the English ambassador, and to go and reside in London : but it was to no purpose; he never would consent to expatriate himself, and carry his discoveries and knowledge out of his native country. When Sully died, which happened in October 1 728, Julien Le Roy was pressed to solicit the pension from the king, which Sully had received; but he constantly refused it, because madame Sully had requested the king to continue it to her. The same zeal engaged him to undertake every thing that could do honour to the memory of his departed friend; and it is to him we are indebted for the little that is known of Sully's life. Notwithstanding his continual occupations, Le Roy undertook the reprinting one of his works, and enriched it with every thing that could recommend it. He might have intermixed his own subjects with Sully's; but he chose rather to bring forward his name and writings after those of his deceased friend, and to print a part of his Memoirs at the end of the Règle artificielle du Temps.

Such was this celebrated man; to whom was given, if I may use the expression of a celebrated journalist, the art of chaining down time, and forcing matter to represent with the utmost precision the rapid flight of our years. The king deigned to honour him with his regret when he heard 
of his death. By his marriage with Jane De Lafons he left four sons worthy of such a father; and who have all distinguished themselves in the departments which they have chosen :-Peter Le Roy, the eldest, who has succeded his father as clock- and watch-maker to the king, and who is the inventor of the marine watches; John Le Roy, of the Royal Academy of Sciences; Julien David Le Roy, professor in the Royal Academy of Architecture, and of the Institution of Bologne, author of the Ruins of Greece; and Charles Le.Roy, of the Royal Academy of Montpellier, correspondent of the Academy of Sciences of Paris, and professor of medicine in the University of Montpellier.

III. An Essay on Commerce, as at present carried on by different Nations; with some Hints, which the Writer thinks would tend greatly to the Advantage of every Country. By Mr. James Graham, of Berwick-uponTweed*.

C Commerce has long been the distinguishing characteristic of this country: it is the great source of our national wealth as well as individual riches. It is commerce that rouses and calls forth the adventurous spirit of our merchants and the persevering industry of our manufacturers. To carry the various produce of our country to the remotest part of the earth gives employment to our sailors, whose valour and intrepidity are the admiration of Europe, and give to Britain that preeminence amongst the nations which she now possesses.-If such are the great advantages derived from commerce to this country, it surely ought to be the study of every individual, as far as his abilities, situation, and circumstances in life will admit, to be acquainted with its nature, and to trace its various connections.

To make some observations on the first principles of trade, or the beginning of commercial intercourse with different countries, and to point out what to me appears the most

* Read before the Literary Society of Newcastle -upon-Tyne.

likel: 